\title{
Complex procedures as hurdle to accountability: verticalization of pharmaceutical enforcement
}

Citation for published version (APA):

Chamon, M., \& Röttger-Wirtz, S. (2017). Complex procedures as hurdle to accountability: verticalization of pharmaceutical enforcement. In M. Scholten, \& M. Luchtman (Eds.), Law enforcement by EU authorities: Implications for political and judicial accountability (pp. 141-167). Edward Elgar Publishing. https://doi.org/10.4337/9781786434630.00012

Document status and date:

Published: 01/01/2017

DOI:

10.4337/9781786434630.00012

Document Version:

Publisher's PDF, also known as Version of record

\section{Please check the document version of this publication:}

- A submitted manuscript is the version of the article upon submission and before peer-review. There can be important differences between the submitted version and the official published version of record.

People interested in the research are advised to contact the author for the final version of the publication, or visit the DOI to the publisher's website.

- The final author version and the galley proof are versions of the publication after peer review.

- The final published version features the final layout of the paper including the volume, issue and page numbers.

Link to publication

\footnotetext{
General rights rights.

- You may freely distribute the URL identifying the publication in the public portal. please follow below link for the End User Agreement:

www.umlib.nl/taverne-license

Take down policy

If you believe that this document breaches copyright please contact us at:

repository@maastrichtuniversity.nl

providing details and we will investigate your claim.
}

Copyright and moral rights for the publications made accessible in the public portal are retained by the authors and/or other copyright owners and it is a condition of accessing publications that users recognise and abide by the legal requirements associated with these

- Users may download and print one copy of any publication from the public portal for the purpose of private study or research.

- You may not further distribute the material or use it for any profit-making activity or commercial gain

If the publication is distributed under the terms of Article $25 \mathrm{fa}$ of the Dutch Copyright Act, indicated by the "Taverne" license above, 
be identified with regard to the (shared) enforcement powers exercised by EASA and the NAAs in the MS. Moreover, no overarching accountability mechanism accounting for the 'sharedness' of the enforcement of the EU aviation safety legal framework could be identified. The current political accountability mechanisms regarding EASA as compared with the NAAs in the MS reflect slightly differently Bovens' three stages of accountability. Furthermore, assessing the extent to which they could result in accountability gaps is difficult. Arguably, potential or actual accountability gaps could be partly compensated for by alternative internal and external review mechanisms existing at EU and national levels, such as the accountability relationship between the EASA Executive Director and EASA MB, or the supervisory and instructions powers exercised over NAAs by their respective ministries.

More accountability, however, might not necessarily be the (only) way forward. In this respect, the argument could be made that the increasing involvement of political bodies with regard to direct enforcement powers in the aviation safety area is not desirable, as it could jeopardize the technical independence of EU and national safety agencies, and make enforcement of aviation safety standards in individual cases subject to unwarranted political interference. Accountability should be rather focused on policy choices, where the Agency is subject to scrutiny of the Commission and EASA MB, in particular regarding its work programme. The ultimate accountability is with the Executive Director of the Agency, who is appointed and can be dismissed by the MB.

\section{Complex procedures as hurdle to accountability: verticalization of pharmaceutical enforcement}

\section{Merijn Chamon and Sabrina Wirtz}

\section{INTRODUCTION}

The legislative framework of pharmaceuticals regulation in the internal market is foremost defined at EU level, with important areas subject to complete harmonization. In addition, even if most authorizations are granted by the national authorities, significant examples of direct administration may be noted, such as the centralized procedure for granting marketing authorizations whereby the Commission and the European Medicines Agency (EMA), which itself draws its expertise from the Member States (MS), cooperate to grant a single EU authorization. Today, following the EMA's 20th anniversary in 2015, which coincided with the 50th anniversary of the first EU legislation on pharmaceuticals, ${ }^{1}$ the area in general is subject to significant Europeanization. As a result, it is an interesting area of regulation that illustrates how the verticalization of the enforcement of EU legislation can start very modestly.

As will be shown, enforcement powers in our case study are predominantly shared, in the sense that the EU enforcement authority relies on the national authorities. However, a parallel enforcement power has been created with the Penalties Regulation which allows for EU level sanctions. ${ }^{2}$ Moreover, the Urgent Union Procedure shows characteristics of subordinate enforcement. ${ }^{3}$ In this enforcement structure, challenges to

1 Council Directive 65/65/EEC of 26 January 1965 on the approximation of provisions laid down by Law, Regulation or Administrative Action relating to proprietary medicinal products [1965] OJ 22/369.

Commission Regulation (EC) 658/2007 of 14 June 2007 concerning financial penalties for infringement of certain obligations in connection with marketing authorizations granted under Regulation (EC) No 726/2004 [2007] OJ L155/10.

3 Directive 2001/83/EC of the Parliament and Council of 6 November 2001 
Table 6.1 The Belgian and German pharmaceutical sectors

\begin{tabular}{lcccccc}
\hline Share in & $\begin{array}{c}\text { Share in } \\
\text { EU GDP }\end{array}$ & $\begin{array}{c}\text { Share in EU pharma } \\
\text { production }\end{array}$ & $\begin{array}{c}\text { Share in } \\
\text { wU pharma } \\
\text { workforce }\end{array}$ & $\begin{array}{c}\text { Share in } \\
\text { EU RD }\end{array}$ & $\begin{array}{c}\text { Share } \\
\text { in EU } \\
\text { pharma } \\
\text { R\&D }\end{array}$ \\
\hline BE & $2.3 \%$ & $3.7 \%$ & $1.8 \%$ & $4.7 \%$ & $3 \%$ & $8 \%$ \\
GER & $15.3 \%$ & $13 \%$ & $15.8 \%$ & $15.5 \%$ & $26.7 \%$ & $20 \%$ \\
\hline
\end{tabular}

accountability mainly result from the complexity of the composite procedures which have been put in place.

\subsection{The Belgian and German Authorities}

The two MS on which we will focus are Belgium and Germany since both countries have a strong pharmaceutical sector. Bringing together data from the annual European Federation of Pharmaceutical Industries and Associations (EFPIA) report and OECD statistics allows us to illustrate this with some key figures (Table 6.1). ${ }^{4}$

While the figures for Germany show that the German part of the European pharmaceutical sector is roughly proportionate to Germany's position in the European economy, the figures for Belgium show that it has a 'disproportionately' large pharmaceutical sector. ${ }^{5}$ Also, the institutional structure of pharmaceuticals regulation enforcement within Belgium and Germany makes these countries interesting case studies, as they responded differently to the increasing integration of national regulators into a European network of pharmaceutical regulators. The Belgian Federal Agency for Medicines (FAMHP) was established in $2006,{ }^{6}$ as an autonomous agency to allow these tasks to be performed more efficiently, under the assumption that an agency would be able to be integrated more

on the Community code relating to medicinal products for human use [2001] OJ L311/67, art 107i(1).

4 See European Federation of Pharmaceutical Industries and Associations, The Pharmaceutical Industry in Figures, 2015; OECD Data retrieved from <https:/ data.oecd.org/> accessed 22 August 2016. The figures in Table 6.1 result from own calculations based on the EFPIA and OECD data.

5 In this paragraph, 'European' does not mean 'EU' since some EFPIA (associated) members are non EU-countries.

6 Law of 20 July 2006 on the establishment and functioning of the Federal Agency for Medicines and Health Products, Belgisch Staatsbald/Moniteur belge 8 September 2006, p. 45714. easily into the European network. ${ }^{7}$ In contrast, the German government's proposal to turn the Federal Institute for Drugs and Medical Devices (BfArM) into an agency, ${ }^{8}$ to make it more competitive in the European context, ${ }^{9}$ failed and the BfArM remained a higher federal authority under the portfolio of the Federal Ministry of Health. ${ }^{10}$

\subsection{The Institutional Structure of the Enforcement of EU Pharmaceuticals Regulation}

The next sections provide short presentations of the relevant enforcers, including their tasks and institutional setup.

\subsubsection{The European Medicines Agency}

At the EU level, the EMA fulfils an important role in the enforcement of pharmaceutical regulation, although, unlike the framework governing, for example, the European Aviation Safety Agency (EASA), ${ }^{11}$ it will generally be the Commission that adopts final binding decisions. The EMA was established in $1993,{ }^{12}$ to infuse the EU decision-making process with independent scientific and technical expertise. ${ }^{13}$ Its creation built on 30

7 See the Report of the Committee on the legislative proposal establishing a Federal Agency for Medicines and Health Products, Chamber of Representatives, 2005-2006, 19 May 2006, nr. 2437/003, 3-4.

8 Gesetzentwurf der Bundesregierung, Entwurf eines Gesetztes zur Errichtung einer Deutschen Arzneimittel-und Medizinprodukte Agentur (DAMAErrichtungsgesetz), 23 February 2007, 16/4374.

9 Bundesministerium für Gesundheit, Press Release: Wettbewerbsfähige Arzneimittelzulassung bringtmehr Sicherheit bei Arzneimitteln und Medizinprodukten und stärkt den Wirtschaftsstandort, 1 March 2007.

${ }_{10}$ See also: R Kurth, 'Die Entwicklung des Bundesinstituts für Arzneimittel und Medizinprodukte (BfArM) im zunelimenden europäischen Wettbewerb' (2008) 51 Bundesgesundheitsblatt - Gesundheitsforschung - Gesundheitsschutz $340,340-44$

11 See Chapter 5 , this volume.

12 The EMA was created through Council Regulation (EEC) 2309/93 of 22 July 1993 laying down Community procedures for the authorization and supervision of medicinal products for human and veterinary use and establishing a European Agency for the Evaluation of Medicinal Products [1993] OJ L214/1. This Council Regulation was replaced by Regulation (EC) $726 / 2004$ of the European Parliament and of the Council of 31 March 2004 laying down Community procedures for the authorisation and supervision of medicinal products for human and veterinary use and establishing a European Medicines Agency [2004] OJ L 136/1, which now regulates the mandate and functioning of the EMA.

13 The description 'non-majoritarian agencies' is used to refer to the fact that, although carrying out a public function, these bodies are independent from elected 
years of prior EU pharmaceuticals legislation, as the Agency integrated pre-existing comitology committees. ${ }^{14}$

General tasks EMA's general task consists in advising the MS and the EU institutions on the quality, safety and efficacy of medicinal products..$^{15}$ Its primary task is to provide scientific advice to the Commission in the centralized marketing authorization procedure. Over the years, the EMA has also obtained a mandate to coordinate pharmacovigilance measures, which are concerned with gathering data about adverse effects of pharmaceuticals, after their marketing authorization, and addressing them. ${ }^{16}$ In this regard, pharmacovigilance is an important part of the regulatory framework: no matter how carefully medicines are assessed at the authorization stage, adverse drug reactions might occur once the product is marketed and accessible to a larger group of patients.

General institutional setup The EMA, like the EASA, European Fisheries Control Agency (EFCA) and the European Securities and Markets Authority (ESMA), ${ }^{17}$ is a decentralized agency of the EU and enjoys legal personality under its founding regulation. ${ }^{18}$ The EMA is headed by an Executive Director and governed by a Management Board, and further consists of seven scientific committees and a secretariat charged with the technical, scientific and administrative support of the committees. ${ }^{19}$ The Management Board of the EMA is composed of one representative of each MS, two representatives of each of the Commission and the Parliament, as well as four stakeholder representatives. ${ }^{20}$

The Committee for Medicinal Products for Human Use (CHMP) forms the main scientific committee for evaluating medicines for humans. Next to the CHMP, six other specialized committees such as the Pharmacovigilance

politicians. See: D Curtin, 'Delegation to EU Non-Majoritarian Agencies and Emerging Practices of Public Accountability' in D Gerardin, R Muñoz and N Peti (eds), Regulation Through Agencies in the EU: A New Paradigm of European Governance (Edward Elgar Publishing 2006) 92.

14 See also M Groenleer, The Autonomy of European Union Agencies - A comparative study of institutional developments (Eburon 2009) 145.

$15 \operatorname{Reg} 726 / 2004$, art $57(1)$

16 Ibid., art 57(1)(c)-(f)

7 For EASA see Chapter 5, this volume; for EFCA see Chapter 7, this volume; and for ESMA see Chapter 3, this volume.

18 Ibid., art 71 .

19 Ibid., art 56

20 Ibid., art 65
Risk Assessment Committee (PRAC) provide scientific advice. ${ }^{21}$ The large majority of the committee members are representatives of the national competent authorities and are appointed by the MS, after consultation with the agency's Management Board..$^{22}$ The total number of agency staff, including trainees and national experts, exceeded 800 in $2014 .{ }^{23}$ In 2015 the EMA operated on a budget of $€ 302$ million of which only some 11 per cent came from the general EU budget. ${ }^{24}$ Furthermore, the agency brings together and coordinates the national agencies tasked with the authorization of pharmaceuticals, making the EMA the centre of a large regulatory network of national regulatory authorities. ${ }^{25}$

\subsubsection{The national authorities}

General tasks The general objective of both the FAMHP and BfArM is to ensure the safety and efficacy of medicines and medical devices. ${ }^{26}$ They decide, inter alia, on requests for marketing authorisations; implement the pharmacovigilance system; monitor the manufacturing and distribution of medicines and assist the government by proposing new legislation and by enforcing existing relevant legislation.

General institutional setup The FAMHP has been established as a type A agency as envisaged in the law of 16 March $1954 . .^{27}$ This means that it is a functionally decentralized agency with a separate legal personality functioning under the hierarchic authority of its parent Minister. Despite its own legal personality, the FAMHP acts in the name and on behalf of

21 Ibid., art. 56.

22 Ibid., art 61(1).

23 EMA, Annual Report 2014, 64

4 See EMA, Annual Activity Report 2015, 76. This means that the EMA is mainly funded through fees charged to market operators.

25 For further detail on the network character of the EMA see: $R$ Dehousse, 'Regulation by Networks in the European Community: The Role of European Agencies', (1997) 4 Journal of European Public Policy 246-61; A Spina, 'The Regulation of Pharmaceuticals Beyond the State: EU and Global Administrative Systems' in E Chiti and B Mattarella, Global Administrative Law and EU Administrative Law (Springer 2011) 249--68.

20 Law of 20 July 2006, Belgisch Staatsblad/Monileur belge, 8 September 2006, p. 45714; Law on the succeeding institutions for the Federal Health Office, 24.06.1994, BGBl. I p. 1416, para 1(3); Medicinal Products Act, 24.08.1976, BgBl. I, p. 3394, para 62 jo. 77 .

27 Law of 16 March 1954 on the control of some public interest entities, Belgisch StaatsbladlMoniteur belge, 24 March 1954, p. 2210. 
the State. ${ }^{28}$ The FAMHP is headed by the Administrator General, who is appointed by the government for a six-year renewable term and who may act as the representative of the Minister of Public Health (allowing the Administrator General to e.g., grant marketing authorizations). Apart from the supporting services, the FAMHP consists of three main policy divisions: DG pre-authorization, DG post-authorization and DG inspection. The FAMHP's total staff numbers about 400, mainly people with a scientific background.

The BfArM is established as an independent higher federal authority within the portfolio of the Federal Ministry of Health. The basis for the establishment of such higher federal authorities is Article 87 (3, 1st sentence) of the German Constitution (Grundgesetz). The BfArM does not have its own legal personality but is immediately subordinated to the Federal Ministry of Health. It is strictly limited to the tasks mandated by law or given to it by the ministry. ${ }^{29}$ The BfArM is headed by a President who, as a civil servant, is in principle appointed for life by the Federal President. ${ }^{30}$ The candidate is appointed on the proposal of the Minister of Health, subject to the approval of the federal cabinet. ${ }^{31}$ The President oversees the working of currently more than 1,000 employees, ${ }^{32}$ of whom more than $50 \%$ are working in the marketing authorization of pharmaceuticals. ${ }^{33}$

\section{ENFORCEMENT IN THE REGULATION OF PHARMACEUTICALS}

In line with the rule of indirect administration of EU law, EU authorities hold few direct enforcement powers in the area of pharmaceuticals. However, as the field is being progressively regulated at the EU level, several instances of a verticalization of enforcement may be noted. Looking at the issue from the perspective of the three stages of enforcement, the current framework envisages a coordinating role for the EMA in monitoring and investigating, which will therefore still be done by the

28 Law of 20 July 2006 , art 4, para 2.

29 Law on the succeeding institutions for the Federal Health Office, para 4.

30 Federal Civil Servants Act, 05.02.2009, BgBl. I, p.160, para 10 jo. 12; see also Kurth (n 10) 343.

${ }_{31}$ See <http://www.bmg.bund.de/presse/pressemitteilungen/2014-03/neuer-prae sident-des-bfarm.html $>$ accessed 10 October 2016.

32 See <http://www.bfarm.de/DE/BfArM/_node.html $>$ accessed 22 August 2016.

33 Kurth (n 10) 340 national authorities. Sanctioning as well is a prerogative of the national authorities, albeit that two interesting sanctioning powers are also given to EMA and the Commission. The complex procedures set up to this end are subsidiarity-inspired: while in the protection and improvement of human health the EU can only act in a supporting capacity (according to art 6(a) TFEU), the harmonization of pharmaceutical policy is based on the shared competence of regulating the internal market (art 4(2)(a) TFEU) and the shared competence for common safety concerns in public health matters as provided for in the Treaties (art 4(2)(k) TFEU).

In what follows, we will first look at the general enforcement powers and tasks of the national authorities, consisting of inspections and sanctioning of infringements. Following this we will examine the verticalization of enforcement, illustrating this with two specific instances of enforcement: the imposition of a penalty under Regulation 658/2007 (the Penalties Regulation) and the use of the Urgent Union Procedure under Article 107i of Directive 2001/83.

\subsection{General Enforcement Powers: Inspections and Sanctioning Through National Authorities}

While the rule of indirect administration of EU law leaves it to the MS to implement, and thus also enforce, EU legislation, EU law may still set certain minimum requirements or a framework within which the MS are to take the 'appropriate measure[s], general or particular, to ensure fulfilment of the obligations arising out of the Treaties or resulting from the acts of the institutions of the Union' ${ }^{34}$ Thus, both the Regulation establishing the EMA as well as Directive 2001/83 instruct the MS to ensure that effective, dissuasive and proportionate sanctions are put in place for infringements of the provisions of the Regulation or the Directive. ${ }^{35}$ Further, title XI of the Directive sets out the rules on supervision and sanctions and requires the MS to put in place a system whereby the national competent authorities have far-reaching supervisory powers. Supervising compliance of the Regulation is also entrusted to the national authorities, with Articles 19 and 20 cross-referencing to title XI of the Directive, thereby ensuring that national authorities have the same tools at their disposal for supervising compliance with both the Directive and the

34 See TEU, art 4

35 See Directive 2001/83 of the Parliament and Council of 6 November 2001 on the Community code relating to medicinal products for human use [2001] OJ L311/67, art 118a; Regulation 726/2004 [2004] OJ L 136/1. 
Regulation. Generally, because of this EU framework, the accountability for these enforcement tasks should not be limited to actors at the national level but also extend to the EU level when enforcement practices have an EU dimension.

\subsubsection{Inspections}

Article 111 of Directive 2001/83 requires the MS to enforce the pharmaceutical laws through inspections, which are to be carried out unannounced if necessary, while information on both planned and performed inspections are to be shared with the Agency. These inspections, according to Article 111a of the Directive, are subject to common principles, which are defined by guidelines adopted by the Commission. In this regard, the German Medicinal Products Act, for example, makes it clear that the inspections have to be carried out in accordance with these guidelines. ${ }^{36}$ The inspection powers of the competent authorities are thus clearly embedded in a EU context. Even more so, the EMA coordinates inspections requested by the CHMP with regard to centrally authorized products and also organizes regular meetings between national inspectors, for example in the framework of the Good Clinical Practice Inspectors Working Group or the Pharmacovigilance Inspectors Working Group, where common inspection guidelines are drafted.

The applicable legislation in both countries requires the authorities to cooperate with the EMA and other national authorities, sharing information on inspections and organizing inspections at the request of the Commission, the EMA or another Member State. ${ }^{37}$ What is then shared in this inspection power (both at the monitoring as well as at the investigating stage) is that the national authorities remain the "boots on the ground', whereas the overarching approach is rather informally settled at the EU level. In this sense the EMA differs from bodies like OLAF and EASA, because it does not have autonomous investigative powers. While the specific inspection acts may therefore still be scrutinized at national level, this may be cumbersome for the coordinating activities at the EU level. Here accountability will be straightforward

36 Medicinal Products Act, para 64(3b). While a similar explicit reference for the conduct of inspections is not taken up in Belgian legislation, the explanatory memorandum of the relevant Royal Decree does indicate (generally) that the guidelines interpret the Directive for the purpose of its implementation. See the Royal Decree of 14 December 2006 concerning medicines for human and veterinary use, Belgisch Staatsblad/Moniteur belge, 22 December 2006, p. 74016.

37 Law of 25 March 1964, art 14ter; Medicinal Products Act, para 64(3b) and if an inspection has been performed following a formal request by the EMA (as illustrated by the Roche case, see Section 3.4 .2 below), but ensuring political and judicial accountability will be more problematic if one is confronted with an informal agreement between national authorities coming together within the EMA to agree on a plan of action for ongoing inspections. For such agreements the EMA would be the wrong actor to hold to account, while relying on national accountability mechanisms would be ineffective.

Inspection powers of the national authorities In Belgium, one of the FAMHP's tasks is to monitor, enforce and ensure the application of a number of laws, including the law of 25 March 1964 on medicines. This law entrusts its enforcement to the employees of the FAMHP.

In Germany, the enforcement of the Medicinal Products Act is generally entrusted to the federal states (Bundesländer). ${ }^{38}$. However, where the Medicinal Products Act specifically provides it, a competent higher federal authority, such as the BfArM, is also granted enforcement powers. This division of tasks is further clarified in a general administrative instruction. ${ }^{39}$

The specific enforcement powers, which the national functionaries may exercise during inspections, are fairly similar in Belgium and Germany. ${ }^{40}$ In both countries, the authorities mandated to carry out inspections are entitled to enter and inspect premises during normal business hours. These inspections may be unannounced. During the inspections, the officials are entitled to request information from persons and to request documents in any form, which includes the right to make copies of such documents or data. Moreover, these inspections may be documented through audio or video recordings. A difference exists between the protection of residential premises, as in Belgium an inspection of inhabited premises requires prior permission from the police court (the court dealing with minor and traffic offences) regardless of when an inspection is performed. In Germany, the inspections might be extended to residential housing in a case of imminent

38 Basic Law for the Federal Republic of Germany, 23.05.1949, BGB1. III, 100-1, art 83; Medicinal Products Act, para 64

39 General Administrative Regulation on the Execution of the Medicinal Products Act, 29.03.2009, BAnz., p. 2287.

40 Law of 25 March 1964, art 14, para 2, $2^{\circ}$; Medicinal Products Act, para 64(4). In Belgium, other investigative measures are not envisaged and would therefore require the intervention of an investigating judge who may allow such measures to be taken by the judicial police at the request of the public prosecutor. 
danger to public order and security and the Medicinal Products Act in this case does not require the authorization of a court. ${ }^{41}$

In Belgium, the FAMHP's functionaries are empowered to issue warnings to offenders, to impose deadlines for compliance and to draw up authenticated accounts which have conclusive force but which may be rebutted. ${ }^{42}$ These procès-verbaux may also be used by other civil servants and services entrusted with the enforcement of different laws. ${ }^{43}$ If necessary, the FAMHP's functionaries may be assisted by police officers. ${ }^{44}$ At the same time, the FAMHP's inspectors can also assist the judicial police. In this regard, there is some useful clarification by the Court of Cassation of the Food Safety Agency's inspection powers (which are very similar to those of the FAMHP): the agency's assistance is covered by the police search warrant and does not require a separate approval from the police court. At the same time the agency is not prevented during such an inspection from making discoveries of new facts which were not the subject of the original warrant. As long as the acts of the agency are covered by the original warrant, the right to a fair trial will not be violated. 45

Following an inspection, both Belgian and German law provide that the inspected company is to be informed of the authority's findings and to be granted the opportunity to make remarks. ${ }^{46}$ Moreover, the German competent authority may make provisional orders, including the closing of the premises, where this is necessary for the prevention of imminent danger to public order and safety. ${ }^{47}$ Where the authorities find infringements, they may issue directives to remedy any offences and to inhibit future offences, including the prevention of marketing of the concerned product, as well as recalling or seizing it. ${ }^{48}$ These measures are subject to administrative discretion with regard to whether or not they should be taken and with

41 Medicinal Products Act, para 64(4)

42 This is an exception to the general rule that procès-verbaux merely have informative value. See also Xirius-Altea, 'Article 14, \&3', in pharma.be, Codex Pharma CommentélBecommentarieerde Codex Pharma (Knopspublishing 2013) 219.

43 Law of 25 March 1964, art 14, para 3.

44 Ibid., para 4.

45 Cass. 30 October 2012, P.12.0330.N. Confirming the ruling of the Hof van Beroep Antwerpen (10 Kamer), 11 January 2011, AR 2010PGA001836.

46 Law of 25 March 1964, art 14, para 6; Medicinal Products Act, para 64(3d).

47 Medicinal Products Act, para 64(4); similarly for the Belgian authority, see Law of 25 March 1964, art 14, para 2, $2^{\circ}(\mathrm{e})$

48 Medicinal Products Act, para 69; Law of 25 March 1964, arts 8, 8bis and 14 , para 3. regard to their content, subject to the principle of proportionality. ${ }^{49}$ In the case of products that have been authorized under the centralized $\mathrm{EU}$ procedure, the BfArM will inform the CHMP and will limit itself to measures urgently needed to protect public health, animal health or the environment, before the Commission has taken action. ${ }^{50}$

\subsubsection{Sanctioning}

In both countries pharmaceutical legislation is enforced through criminal and administrative sanctions.

In Belgium, infringements of some of the provisions of the law of 25 March 1964 (and relevant European legislation including the EMA Regulation) are identified as punishable under criminal law. ${ }^{51}$ For every infringement found, the FAMHP is instructed to send a procès-verbal to the public prosecutor, but the.FAMHP may also propose an administrative settlement which, if complied with, will normally result in the prosecution being withdrawn, unless the public prosecutor decides to pursue the prosecution. ${ }^{52}$ According to commentators, this possibility of an out of court settlement explains the lack of any (documented) criminal convictions for infringements of the law of 25 March $1964 .{ }^{53}$ In Germany, depending on which obligation under the Medicinal Products Act has been infringed, $\$ 95$ and $\$ 96$ of the Medicinal Products Act with regard to penal provisions or $\$ 97$ with regard to administrative fines will apply. Where penal provisions are concerned, the case will be handed over to the competent public prosecutor. When exercising those powers, the national

B Mainz-Kuhlmann, '\$26 Pharmakovigilanz' in S Fuhrmann, B Klein and A Fleischfresser, Arzneimittelrecht (Nomos 2014) 711, Rn. 112-113.

50 Medicinal Products Act, para 69(1a). This applies to products authorized under Regulation $726 / 2004$, within the framework of the recognition procedure under Chapter 4 of Directive 2001/83 and on the basis of an expert opinion of the Committee provided for in Article 4 of Directive 87/22/EEC of 22 December 1986 prior to 1 January 1995. In relation to Belgium, see Law of 25 March 1964, arts 8 and 8 bis.

51 See Law of 25 March 1964, arts 16 and 16 bis.

52 Law of 25 March 1964, art 17, para 1. See also Royal Decree of 23 January 2002, Belgisch Staatsblad/Moniteur Belge, 23 February 2002, p. 7121. Before 2015, the acceptance of the settlement by the offender prevented further (criminal) prosecution, but the Council of State (in its advisory capacity) suggested that the more independent public prosecutor should not be prevented by the administration from acting in the general interest. See Wetsontwerp houdende diverse bepalingen met betrekking tot medische hulpmiddelen, Chamber of Representatives, 2013-2014, 9 October 2013, nrs. $533057 / 001$ and 53 3058/001, pp. 113-14.

53 P Shawn Coulson, 'Article 17' in pharma.be Codex Pharma Commentél Becommentarieerde Codex Pharma (Knopspublishing 2013) 236. 
authorities work autonomously. As the two case studies in Section 2.2 show, the European dimension to enforcement at the sanctioning stage instead results in a concurrent autonomous sanctioning power or in a superseding sanctioning power whereby the national authorities simply become the instruments of the European enforcement authority.

\subsection{Verticalization of Enforcement: the EU Authorities' Enforcement Powers in the Area of Pharmacovigilance}

The following sections will discuss the trend of an increasingly shared EU administration in the remit of pharmacovigilance where the European regulatory framework has advanced from a culture of "passive monitoring to active surveillance'. ${ }^{54}$ However, this should not be understood as meaning that the EMA has become the primary enforcement authority exercising autonomous powers in the three enforcement stages as, e.g., the ESMA does.

To illustrate this point, two distinct procedures in the sanctioning stage will be discussed: the Urgent Union Procedure (UUP) and the procedure whereby the Commission may impose financial penalties on market authorization holders for non-compliance with Regulation 726/2004. These two illustrations have not been selected in a haphazard way: on the one hand, the UUP allows national market authorizations to be revoked, not by the originally competent national authority but through a Union procedure whereby the ultimate decision-making authority is vested in EU authorities. On the other hand, the Penalties Regulation aims to sanction infringements of the Regulation 726/2004, covering centrally authorized products, including infringements of pharmacovigilance obligations. As discussed above, infringements of the Regulation are normally sanctioned by the national authorities, but the Penalties Regulation creates an autonomous sanctioning power for the EU authorities.

\subsubsection{The Urgent Union Procedure}

The UUP is currently laid down in Articles 107i-107k of Directive 2001/83 (see also Figure 6.1 below).

The UUP is initiated by any Member State or the Commission in relation to any authorized medicinal product, where a Member State or the Commission, on the basis of the evaluation of pharmacovigilance data,

54 EMA, Celebrating 20 years (2015) 52, available at $<$ http://www.ema.europa. eu/docs/en_GB/document_library/Brochure/2015/03/WC500184383.pdf $>$ accessed 22 August 2016.

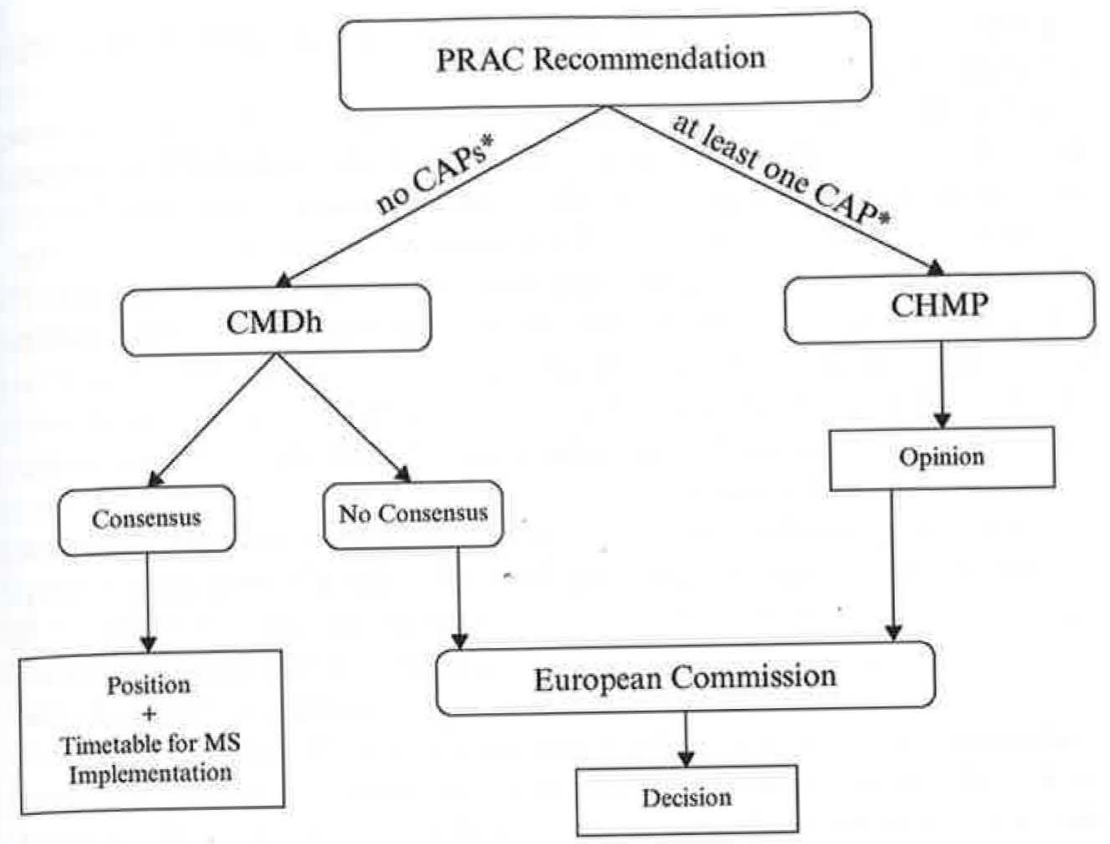

Note: * Centrally authorized product(s).

Figure 6.1 The Urgent Union Procedure

considers suspending or revoking a marketing authorization, suspending the supply of a medicinal product, or refusing the renewal of a marketing authorization and/or is informed by a marketing authorization holder that the marketing of a product has been discontinued due to safety concerns. ${ }^{55}$

The procedure applies to any medicinal product that has been authorized in the Union, irrespective of whether the marketing authorization was granted through a national authority or through the centralized procedure ${ }^{56}$ Moreover, the procedure can cover whole therapeutic classes of products or groups of products with the same active substance, which of products or groups of products with the same active substance we covered by the same procedure. Only where the medicinal product concerned

55 Dir 2001/83, art 107i(1).

56 In a case where only centrally authorized products are concerned, art 20 of Regulation 726/2004 will apply. 
is authorized in only one MS, will the issue be handled by that MS autonomously. ${ }^{57}$

When the procedure is triggered, the PRAC in the EMA will look into the safety issue. ${ }^{58}$ In the meantime, for nationally authorized products, the Commission may request the MS to take temporary measures, ${ }^{59}$ while for centrally authorized products the Commission may do so itself. ${ }^{60}$ The PRAC will then make a recommendation on the matter within 60 days. ${ }^{61}$ Where the PRAC is assessing the matter, the marketing authorization holder, the general public and health care professionals are allowed to submit comments in writing. ${ }^{62}$ Moreover, the PRAC may request oral explanations, but the marketing authorization holder does not have a right to present oral explanations. ${ }^{63}$

Where the procedure only concerns nationally authorized products, the PRAC will adopt a recommendation for the Coordination Group for Mutual Recognition and Decentralized Procedures (CMDh). ${ }^{64}$ If the latter by consensus comes to an agreement, the MS will each implement it accordingly. ${ }^{65}$ If no agreement by consensus is reached, the Commission will adopt a decision pursuant to a comitology procedure. ${ }^{66}$ As a result, an EU authority may be given the power to sanction a market player by deciding on the suspension or withdrawal of nationally granted authorizations.

Moreover, as soon as at least one centrally authorized product is concerned, the PRAC recommendation is transferred to the CHMP, which will adopt an opinion on the matter of maintenance, variation, suspension,

57 Dir 2001/83, art 107i(1b)

58 Ibid., art. 107j(2).

59 Ibid., art. 107i(3). Under art 70quater, para 1 of the Royal Decree of 14 December 2006, the Belgian Minister of Public Health (or the FAHMP) is required to immediately adopt any measure so requested by the European Commission.

60 See Dir 2001/83, art 107i(3).

61 Ibid., art $107 \mathrm{j}(3)$.

62 Ibid., art 107j(2); EMA, Questions and answers on Urgent Union Procedures (Article 107i of Directive 2001/83/EC), 3 March 2015, EMA/720443/2012 Rev. 3,8 .

63 Ibid., 15.

64 See Dir 2001/83, art 107j(3). The Coordination Group is not formally a part of the Agency. It is composed of one representative per Member State and the Commission as observer. The Secretariat to the $\mathrm{CMDh}$ is, however, provided by the EMA.

65 Dir 2001/83, art 107k(2).

66 Ibid., art $107 \mathrm{k}(2)$ subsection 3. Under art 70ter, para 2 subs 3 the Belgian Minister of Public Health (or the FAHMP) is required to implement the Commission's decision. revocation or non-renewal of the marketing authorization. ${ }^{67}$ Based on this opinion, the Commission will instruct the MS in which the concerned products are authorized about the measures that should be taken, thereby using them as an extended arm. It will also adopt a decision on the specific centrally authorized products concerned. ${ }^{68}$

The resulting composite procedure is therefore quite complex. Whether the Commission adopts a decision at the end of an UUP depends on whether a centrally authorized product is part of the procedure and, where only nationally authorized products are concerned, on whether a consensus is found in the Coordination Group.

The verticalization of regulation with regard to the UUP is also reflected at the national level in Belgium and Germany. If an UUP is launched for a product that is only authorized in Belgium, the procedure will be directed by the Minister of Public Health. ${ }^{69}$ For products authorized in several MS, the EMA is recognized as the responsible authority ${ }^{70}$ and the relevant Royal Decree provides that the Minister of Public Health will immediately adopt those measures requested by the European Commission. ${ }^{71}$ The German Medicinal Products Act in \$63e also integrates the UUP, stating: 'With regard to the cases governed by Article $107 \mathrm{i}$ of Directive 2001/83/EC, the competent higher federal authority shall take the measures provided for therein. Articles $107 \mathrm{i}$ to $107 \mathrm{k}$ of Directive $2001 / 83 / \mathrm{EC}$ shall apply to the procedure. ${ }^{.72}$ In the case of a Commission decision, the BfArM will adopt measures under $\$ 30$ 1a and $2 \mathrm{a}$ of the Medicinal Products Act. It is interesting in this regard that the right to object to such a decision within an administrative preliminary procedure, as applicable in purely national procedures, does not apply to measures which the BfArM adopts on the basis of the UUP.

\subsubsection{The Penalties Regulation}

In the past, the sanctions available against marketing authorization holders with regard to the enforcement of pharmaceuticals at the EU level were limited to the revocation of or the imposition of variations on the marketing authorization. However, there was no possibility to sanction

67 Dir 2001/83, art 107k(3)

68 Ibid., art $107 \mathrm{k}(4)$. See also the Commission's justification for this instance of verticalization, European Commission, Commission Staff Working Documen SEC (2008) 2670 Vol I, 33

69 Royal Decree of 14 December 2006, art 70bis.

70 Ibid., art 70ter, para 1.

71 Ibid., art 70 quater, para 1.

72 Medicinal Products Act, para 63e. Translation via: < http://www gesetze-iminternet.de/englisch_amg/> accessed 11 August 2016. 
infringements of the legislation if these did not lead to a negative effect on the safety, quality or efficacy of the product. ${ }^{73}$ This has changed with the adoption of the Penalties Regulation.

In post-Lisbon terminology, the Penalties Regulation is a delegated act adopted by the Commission, supplementing the basic Pharmaceuticals Regulation. ${ }^{74}$ Its legal basis is Article 84 of the Pharmaceuticals Regulation which allows the Commission, following a proposal by the EMA, to impose financial penalties. Here EMA's powers are comparable to those of EASA which also (only) has the power to propose a sanction. The Pharmaceuticals Regulation further requires the Commission to make such decisions public.

Further details are worked out in the Penalties Regulation which sets out a list of punishable infringements, including infringements of certain pharmacovigilance obligations. However, the application of the Penalties Regulation is limited to "cases where the infringement concerned may have significant public health implications in the Union, or where it has a Union dimension by taking place or having its effects in more than one Member State, or where interests of the Union are involved' ${ }^{75}$

The infringement procedure itself starts on the EMA's own initiative or at the request of the Commission or a Member State. Article 3 allows the EMA and the Commission to request the national authorities to collect information or perform inspections. The EMA will draw up a report for the Commission, which may decide to pursue the procedure by addressing a statement of objections to the market authorization holder concerned. The latter has a right to reply in writing and to defend its case orally. If the Commission concludes that the market authorization holder has committed an infringement, it may impose a fine not exceeding 5 per cent of the marketing authorizations holder's EU turnover in the previous business year or in the case of ongoing infringements daily penalty payments of 2.5 per cent of the holder's daily average EU turnover. ${ }^{76}$ In deciding on the amount of the penalty,

73 P Bogaert, 'The New EC Financial Penalties Regime - a Bridge Too Far?' (2007/08) Life Science 47, 47.

74 Note that since the Pharmaceuticals Regulation has not yet been amended to take into account the changes brought about by the Lisbon Treaty (arts 290 and 291 TFEU), the Penalties Regulation has not been adopted as a formal delegated act, although it is one in nature.

${ }_{75}$ Commission Regulation 658/2007 of 14 June 2007 concerning financial penalties for infringement of certain obligations in connection with marketing authorisations granted under Regulation (EC) No 726/2004 [2007] OJ L 155/10, art 1 .

76 Ibid., art. 16. the fines imposed at national level for the same infringements must be taken into account. ${ }^{77}$ The decision of the Commission to impose a fine is published (as are the reports by the EMA), which certainly contributes to a practice of 'naming and shaming' next to the actual financial consequences. ${ }^{78}$

\section{ENSURING JUDICIAL AND POLITICAL ACCOUNTABILITY FOLLOWING THE VERTICALIZATION OF ENFORCEMENT}

Before commenting on the challenges to and deficits of the accountability regimes, those regimes will first be briefly presented in a general overview for the three authorities concerned.

\subsection{The European Medicines Agency}

As an EU decentralized agency, the EMA is primarily held accountable, both politically and judicially, by the EU institutions. The EMA's Director is accountable to the EMA Management Board. The accountability of the Board members is not regulated, but insofar as they represent the MS and the Commission, each depends on its principal. In contrast, the individual accountability of the members of the EMA's scientific committees is not set out in the regulation.

As regards the EMA's judicial accountability, the Lisbon Treaty has rectified the most significant lacunae in legal protection by providing that the legal remedies envisaged in the Treaties also apply to the 'bodies, offices and agencies' of the EU, even if it still left some issues open, ${ }^{79}$ notably the question of the EU agencies' internal Boards of Appeal. ${ }^{80}$ However, given the unclear legal nature of the acts adopted by the EMA in the two cases in section 2.2 , it seems doubtful whether these acts could be challenged before the EU courts.

The EMA's accountability is first frustrated by the open-ended nature of the Agency's mandate, which focuses on process (stressing scientific

77 Ibid, art 18(3).

78 Bogaert (n 73) 48.

79 For a discussion, see M Chamon, 'Les agences décentralisées et le droit procédural de l'UE' (2016) 52 Cahiers de droit Européen, 541-574.

80 So far, the EMA, not being a genuine decision-making agency, has not been endowed with its own Board of Appeal; this is different from the EASA and from the ECB's Administrative Board of Review. 
excellence) rather than outcome (public health) ${ }^{81}$ Secondly, the EMA's political accountability is insufficiently worked out in its establishing act, ${ }^{82}$ if accountability is understood as comprising the three stages of providing information, discussing that information and the possibility of rectification ${ }^{83}$ While the Regulation requires the EMA to present an annual work programme and an annual report on its functioning to the EU institutions and MS, it does not make explicit how the report can be discussed. Formally, the only hearings (of the Director) before the Parliament take place during the appointment procedure. ${ }^{84}$ That being said, an informal practice of hearings before the Parliament does exist. ${ }^{85}$ This is different for the Council which, generally, does not seem to concern itself with the actual functioning of EU agencies. ${ }^{86}$

In all, this means that there are no political accountability mechanisms specific to the EMA's enforcement tasks and also that the reporting obligations only partially cover the enforcement tasks of the EMA. The annual activity reports cover enforcement insofar as they contain a section on inspections, in which the number of inspections carried out is stated and certain performance indicators, such as the timely completion of the inspections within the allotted timeframe, are specified. ${ }^{87}$ In addition, achievements of a more general managerial nature, such as making inspections more efficient through cooperation with third-country authorities, are covered. ${ }^{88}$ Thus, accountability for the inspection requests and coordination through the Agency based on the reports is more managerial, rather than substantively providing an account of how the inspections are carried out. The annual reports do not cover sanctions of the national authorities, and the UUP and the use of the Penalties Regulation are also not reported on, which is partly explained by the fact that the Penalties Regulation has not been fully used yet.

The two main elements that allow for rectification and sanctioning then are the discharge procedure and the revision of the legislative mandate..$^{89}$

81 See also Chapter 11.

$82 \mathrm{M}$ Scholten, The Political Accountability of EU and US Independent Regulatory Agencies (Brill 2014) 434-5.

83 See Chapter 1 , section 2.3 .

84 See EMA Regulation, art 64(1).

85 See M Busuioc, European Agencies: Law and Practices of Accountability (OUP 2013) 104-5.

86 Ibid., 120; M Chamon, EU Agencies: Legal and Political Limits to the Transformation of the EU Administration (OUP 2016) 319.

87 EMA, Annual Activity Report 2015, 49ff.

88 Ibid., $51 \mathrm{ff}$.

89 Since the EMA Director can only be removed by the EMA Board, it is difficult to qualify it as an instrument to hold the EMA accountable, unless the
The latter is obviously cumbersome and requires an agreement between the three institutions, insulating the Agency from the risk of any real sanction. Under the budgetary procedure the Commission, acting as an account holder, may propose a lower subsidy for the Agency in its budgetary proposals. The Parliament, possibly following the opinion of the Court of Auditors, may refuse to or only conditionally grant the Agency a discharge. Where the Parliament discovers systemic governance problems within the EMA, it can use its budgetary powers to hold the Agency accountable. Indeed, the Parliament has used the budgetary discharge procedure to address non-budgetary issues, ${ }^{90}$ and it has not shied away from postponing the discharge to put pressure on the Agency, as it did with regard to the budgets of 2009 and 2010 due to concerns with regard to the independence of experts. ${ }^{91}$ Similarly, the Parliament could sanction the EMA for its enforcement activities by freezing specific budget appropriations.

\subsection{The Belgian Federal Agency for Medicines and Health Products}

Since the FAMHP is an administrative authority, its decisions are challengeable before the Council of State, with a possibility of interim relief before the Council of State (or the civil magistrate). Compensation for damage resulting from wrongful conduct by the FAMHP may likewise be sought before an ordinary judge. Judicial scrutiny of the FAMHP's enforcement powers is also possible by a criminal court judge, i.e., when the findings of the FAMHP's inspections are contested in criminal proceedings. ${ }^{92}$

Commission's proposal (to the EMA Board) to remove the Director is taken into account.

90 For example, in the budgetary discharge procedure for the year 2014, the Parliament asked the Agency to ensure transparency with regard to clinical trials data. See: European Parliament Resolution of 28 April 2016 with observations forming an integral part of the decision on discharge in respect of the implementation of the budget of the European Medicines Agency for the financial year 2014 (2015/2171(DEC)).

European Parliament Decision of 25 October 2011 on discharge in respect of the implementation of the budget of the European Medicines Agency for the financial year 2009 [2011] OJ L313/27; European Parliament Decision of 10 May 2012 on discharge in respect of the implementation of the budget of the European Medicines Agency for the financial year 2010 [2012] OJ L350/82.

${ }_{92}$ Further, the Belgian Constitutional Court has ruled that the enforcement of competition rules is sufficiently comparable to criminal investigations, meaning that the same level of protection as that applicable in criminal proceedings should be afforded to undertakings faced with enforcement actions. Since the FAMHP's 
Each year, the FAMHP is required to send a report to the Parliament and the parent Minister on its functioning. ${ }^{93}$ Other than this, no direct parliamentary control is provided which may be explained by the fact that the FAMHP is not an independent agency but remains under the hierarchic authority of the Minister of Public Health. As a result, direct parliamentary control was not considered necessary and de jure the system of accountability is watertight. However, it may be more of a legal fiction than reality to claim that the government (or Minister) may be held accountable for the activities of a functionally decentralized body such as the FAMHP. As regards financial independence, the FAMHP depends for 25 per cent of its budget on a grant from the government, whilst the rest of its income is generated by charges and fees paid by companies.

\subsection{The German Federal Institute for Drugs and Medical Devices}

As part of the administration, the BfArM is subject to the general principle of Article 19(4) of the Grundgesetz which provides a right to judicial review for any act of a public institution that limits the rights of a person. This judicial review of administrative acts is exercised by administrative courts, with the possibility of an appeal to an administrative appeal court (Oberverwaltungsgericht) and the Federal Administrative Court (Bundesverwaltungsgericht).$^{94}$ With regard to administrative acts, which are decisions with binding effect in individual cases, the legal basis for an annulment action is $\$ 42$ of the Code of Administrative Court Procedure. ${ }^{95}$ In principle, purely factual acts are also subject to judicial review where they limit the individual right of a person. Taking the example of inspections, whether an inspection report can be legally challenged will depend on the legal basis of the inspection and the question whether the competent authority in the inspection report can make orders that would limit the rights of a person. For inspections carried out by the BfArM in the

inspections are similar to those of the competition authority and may also result in administrative sanctions, the Constitutional Court's decision could be applied analogously to inspections by the FAMHP. See Belgian Constitutional Court, 22 December 2011, 197/2011

93 The Law of 20 July 2006 , art 9 . In practice, the report is not discussed by the competent parliamentary committee.

94 Code of Administrative Court Procedure, 21.01.1960, BGBl. I, p.686, paras $40-53$.

95 Ibid., para 42. The administrative act is defined in Administrative Procedure Act, 25.05.1976, BGBl. I, p. 102, para 35. context of a marketing authorisation procedure, the judicial review of an inspection report was denied. ${ }^{96}$

In addition, the BfArM, although nominally independent, is subject to full ministerial oversight through the Federal Ministry of Health, which encompasses both a legal oversight over the legality of BfArM's activities, as well as functional oversight, which applies to all aspects of the administrative tasks, allowing the Ministry to issue instructions with regard to policy implementation and decisions in individual cases. ${ }^{97}$ Insights from political science research suggest that the Ministry is quite reluctant to interfere with the content of BfArM's decisions; while the Ministry receives reports for example on the BfArM acting as a rapporteur in European authorisation procedures, it refrains from interfering with the content of the reports and with the authorization in order to prevent ethical problems from arising. .98

The Minister in turn is subject to parliamentary control, and parliamentary questions concerning falsified studies and problematic manufacturers of pharmaceuticals in India show that the enforcement of pharmaceutical regulation can also become subject to parliamentary scrutiny; however, this is more likely in exceptional situations where a matter has caught media attention.

Budgetary dependence on the ministry definitely provides for accountability, as the BfArM generates its incomes from fees that are determined by the ministry ${ }^{99}$ and through tax money allocated to the Federal Health Ministry in the Federal Budget.

\subsection{Challenges, Deficits and Risks Following the Verticalization of Enforcement}

As the UUP and the Penalties Regulation illustrate, the verticalisation of enforcement will often result in shared enforcement whereby enforcement

96 VG Köln, Urteil vom 20. November 2012, Az. 7 K 703/11; OVG NordrheinWestfalen, Beschluss vom 18. Dezember 2013, Az. 13 A 107/13.

97 M Ibler, 'Artikel $87 G G$ ' in T Maunz and G Dürig (eds) Grundgesetz: Kommentar (Beck 2015, 76th Edition), paras 250-252; T Bach and W Jann, 'Animals in the Administrative Zoo: Organizational Change and Agency Autonomy in Germany' (2010) 76 International Review of Administrative Science 443 .

98 E Ruffing, 'Inside Regulatory Bureaucracy: When Europe Hits Home in Pharmaceuticals and Chemicals' (2015) Public Policy and Administration 15. Available at <http://ppa.sagepub.com/content/early/2015/12/04/095207671561699 9> accessed 18 August 2016.

99 Law on the succeeding institutions for the Federal Health Office, para 6(2). 
tasks are performed by both national and EU authorities. This shared context means that the accountability mechanisms come under pressure, especially when enforcement tasks are shared in a non-exclusive way, several authorities being competent to take the same enforcement measures. These challenges and risks will be illustrated using the two examples of shared enforcement presented in section 2.2 above.

While several authors point out that multi-level governance results in multiple account holders, ${ }^{100}$ the risk seems to be that since there are many account holders, an agency is really held accountable by none. While we do not subscribe to any thesis claiming that accountability is impossible in a multi-level setting, it seems inevitable that such a setting makes things more complicated. In line with Brandsma, we find that accountability at the macro level depends on the aggregate of micro-level accountabilities. ${ }^{101}$ This requires that the tasks and responsibilities of each different actor be precisely defined and that specific accountability mechanisms are put in place at the micro level. Moreover, while all three authorities studied are - at least to a certain extent - independent, all of them are subject to political and judicial accountability, the efficiency of which, however, depends on how the accountability mechanisms are being used. ${ }^{102}$

\subsubsection{Which political accountability is best suited for enforcement in pharmacovigilance?}

The EMA's political accountability only being partially regulated in its establishing act and the fact that enforcement is not at the core of the Commission's and the EMA's mandates mean that political accountability for enforcement actions is not really on the radar. While this may not be problematic today, since enforcement is only being verticalized on a modest scale, it might have to be addressed explicitly if the political choice is made to push verticalization through.

In this respect, a supranational perspective on accountability, where the European Parliament is the primary actor for holding EU enforcement authorities to account, appears the most promising. After all, current practice reveals the Council's lack of interest in controlling EU agencies,

100 See Y Papadopoulos, 'Accountability and Multi-level Governance: More Accountability, Less Democracy?', (2010) 5 West European Politics 1040-1041, and the authors cited there. ${ }_{44-62}$. See G Brandsma, Controlling Comitology (Palgrave Macmillan 2013)

102 See M Scholten, 'Independent, Hence Unaccountable?' (2011) 4 Review of European Administrative Law 5. while it is questionable whether the MS as such may appropriately hold an EU body to account, ${ }^{103}$ reducing the prospects of the accountability mechanisms being founded on an intergovernmental approach. Alternatively, accountability mechanisms based on a regulatory regimes approach seem difficult to implement as long as the EMA is not a true regulatory agency. Like that of many EU agencies, its role is still limited in light of the Meroni doctrine. ${ }^{104}$

In the future the challenge posed by the composite nature of the enforcement procedures may require greater attention. In the two examples presented above, EU law is enforced in an integrated procedure, national and EU authorities all playing their part. When specific accountability mechanisms for enforcement are worked out, they should reflect this allocation of tasks. Still, even this would not be completely sufficient since, as already noted, the EMA actually draws its expertise from the MS. Using the UUP as an example: how could one hold the EMA politically accountable for a PRAC recommendation, if the PRAC is mainly composed of MS' experts? ${ }^{105}$ While the European Parliament could address the EMA for information and discussion purposes, supranational rectification would seem to be out of place. Here a combination of an intergovernmental approach (national authorities being sanctioned in national accountability forums) and a regulatory regimes approach (self-correction by the epistemic community) would seem to be more appropriate. What at first sight appears to be a question purely related to accountability actually calls into question the very nature of the EU agency.

\subsubsection{Effective legal remedy against enforcement decisions}

Important challenges also arise in the judicial review of composite procedures, e.g., where national inspections are carried out at the request of the CHMP, which later lead to penalties imposed by the Commission. In general, preparatory measures like a CHMP request for an inspection or the CHMP opinion in the UUP are not subject to judicial review under EU law, ${ }^{106}$ unless they affect the legal sphere of the applicant autonomously,

103 M Chamon, EU Agencies: Legal and Political Limits to the Transformation of the EU Administration (OUP 2016) 319, 327.

104 Case 9/56 Meroni v. High Authority, EU:C:1958:7. For instance, the ECB is allowed to exercise significant powers in the Single Supervisory Mechanism in the Banking Union precisely because Meroni's prohibition on the exercise of discretionary powers does not apply to it.

105 See EMA Regulation, art 61a.

106 Case 60/81 IBM v. Commission, EU:C:1981:264. 
regardless of the final decision. ${ }^{107}$ They can, however, be challenged in the context of a procedure against the final act. 108

However, the sharing of inspection information between the national authorities and the EMA might also give rise to questions of national law, as exemplified by a claim brought by Roche against the UK Medicinal and Healthcare Products Regulatory Agency (MHRA). In this case, the EMA had asked the MHRA to perform inspections under the Penalties Regulation. Roche complained inter alia that it had not been properly informed and had been led to believe that it had been subject to a regular routine inspection. The EMA on the other hand claimed that national courts do not have jurisdiction in the first place to hear claims relating to infringements under the Penalties Regulation. ${ }^{109}$ In this case the UK Court of Appeal ultimately decided that the information sharing between the MHRA and the EMA did not infringe the obligation of fairness and the principles applying to declaratory relief under English law, ${ }^{110}$ but the diverging standards in individual protection against enforcement measures in the respective national and European frameworks might lead to gaps in accountability.

This is exemplified by a case where the CHMP requested the inspection of a manufacturing site in India, which was carried out through a German authority. The inspection report documented several infringements of Good Manufacturing Practice, but denied the need to recall the products manufactured on the site. However, both the Commission, for several centrally authorized products, and the BfArM, for a purely nationally authorized product, ordered the company to recall the products. While the General Court and the Court of Justice upheld the Commission's decisions including the product recall for centrally authorized products at the EU level, ${ }^{111}$ based on the Commission's wide discretion under the precautionary principle, ${ }^{112}$

107 Joined cases T-125/03 and T-253/03 Akzo Nobel Chemicals and Akcros Chemical v. Commission, EU:T:2007:287.

108 See e.g. Joined cases T-74/00, T-76/00, T-83/00, T-84/00, T-85/00, T-132/00, T-137/00 and T-141/00 Aitegodan GmbH e.a. v. Commission, EU:T: 2002:283.

109 See $R$ (Roche) v. Secretary of State for Health [2014] EWHC 2256 [77].

110 See $R$ (Roche) v. Secretary of State for Health [2015] EWCA Civ 1311.

111 Case T-539/10 Acino AG v. Commission, EU:T:2013:110; Case C-269/13 P Acino $A G$ v. Commission, EU:C:2014:255.

112 The ECJ confirmed in the Artegodan case that in taking enforcement decisions such as the withdrawal or variation of a marketing authorization the Commission has a large margin of discretion for actions under the precautionary principle. See Joined cases T-74/00, T-76/00, T-83/00, T-84/00, T-85/00, T-132/00, the German court came to the conclusion that the recall was not proportionate. ${ }^{113}$

The Penalties Regulation also shows the risks in verticalizing enforcement powers in a non-exclusive way: if several authorities become competent to sanction one and the same infringement, proper coordination between these authorities is essential. While the Penalties Regulation provides for administrative sanctions, they have a penal character which also explains why the Regulation instructs the Commission, when it imposes a fine, to 'take into account any penalties already imposed on the marketing authorization holder at national level on the basis of the same legal grounds and the same facts'. 14 Since the Commission has, to date, not imposed any sanctions pursuant to the Penalties Regulation, ${ }^{115}$ let alone sanctions concurrent with national sanctions, there is no practice to comment on. In any event, it should be clear that the Commission should do more than simply take into account prior penalties when it imposes new ones, lest it violate the principle of ne bis in idem. ${ }^{116}$

Finally, the complexity of the composite procedures resulting from a verticalization of enforcement may also frustrate effective judicial accountability. This is perfectly illustrated by the different possible outcomes of the UUP, described above. When only nationally authorized products are affected, the procedure does not necessarily culminate in an 'EU' decision. Whether this is the case depends on whether a consensus is reached in the Coordination Group for Mutual Recognition and Decentralised Procedures. Only if no consensus is reached, will the Commission adopt a decision challengeable before the General Court. In the alternative scenario, an affected manufacturer will have to seek legal remedies at the national level, since a private litigant will not be able to challenge the Coordination Group's consensus under Article 263 TFEU.

T-137/00 and T-141/00 Artegodan GmbH e.a. v. Commission, EU:T:2002:283, paras 181, 186, 201.

113 VG Köln, Urteil vom 3. Dezember 2012, Az. 7 K 432/11.

114 See Reg 658/2007, art 18(3).

115 The issue which made the EMA start a procedure under the Penalties Regulation against Roche (see EMA Press Release of 23 October 2012, EMA/666493/2012) was settled between Roche and the Commission before a penalty was imposed.

116 Clearly, the same goes for the national authorities in the event that the Commission has already imposed a penalty. 


\section{CONCLUDING REMARKS}

Going back to the central question of this volume, it is clear that as far as enforcement in pharmacovigilance is concerned, the upgraded role of the EMA has not been accompanied by the creation of special accountability mechanisms. This should not really come as a surprise because the general accountability regime for the EMA is also far from sound: while the three stages of information, discussion and rectification can all be identified, they are rather dissociated from, instead of integrated with, each other. This inter alia explains why, because of the lack of proper rectification mechanisms, the Parliament is using its budgetary powers vis-à-vis the agency in non-budgetary related matters.

In addition, in Belgium and Germany, no specific accountability mechanisms have been introduced at the national level to accompany the specific enforcement tasks entrusted to the national authorities. However, since the national authorities formally act under the hierarchic authority of the government (unlike the EMA), the accountability regime in general is more robust (at least in theory), even if national parliaments do not seem to be particularly concerned with the functioning of the FAMHP and BfArM.

Since the EMA's role in enforcement is still only very modest, it would seem premature to work out specific accountability mechanisms already. Here a wait-and-see approach seems more advisable, whereby lessons may also be learned from the experience gained from other EU enforcement authorities which have been assigned more significant enforcement tasks. The priority in regard to the EMA should instead focus on ameliorating two issues: first, the general accountability regime to which the EMA is subject, where the European Parliament should receive a greater formal role. As noted above, since the EMA is a EU authority, the focus should primarily lie on a supranational accountability regime, possibly supplemented by intergovernmental and regulatory regime accountability mechanisms. Secondly, the procedures on shared enforcement could be simplified, which might also enhance the judicial review possibilities.

When a simplification is contemplated, one should consider that the current complexity partially reflects a subsidiarity concern whereby national authorities are heavily involved in enforcement procedures. As a result, the solution for a simplification of the procedures does not lie in the wholesale transfer of enforcement powers to the EU level. Instead, the composite procedures should be embedded in a sound procedural framework, something for which the ReNEUAL model rules can act as a standard. ${ }^{117}$ The role of the EMA may also be upgraded (at the expense of the Commission) in line with the ECJ's more flexible interpretation, in the Short-selling or ESMA ruling, ${ }^{118}$ of the Meroni doctrine. To compensate, a general hierarchic control of the Commission over the EMA could then be instated.
117 See <http://www.reneual.eu/> accessed 11 August 2016.

118 Case C-270/12, United Kingdom v. Parliament and Council, EU:C:2014:18. 